\title{
DINAMIKA SOSIAL PESANTREN DI INDONESIA \\ Oleh
}

\author{
Fridiyanto
}

Email: fridyanto131@gmail.com

\begin{abstract}
Pesantren is an authentic education of Indonesia. It has social politic dynamics in every periods. Pre Independence Period pesantrenis prohibited by colonial government the Netherlands. In Japan occupationperiod pesantren is annoyed by Japan. After independence 1945, in Old Order, pesantrenis accommodated by government, it is given budget of education. Pesantrens get problems in a time of New Order, Soehartothat is repressive for Islam society. Finally pesantren is assumed as social capital by government in Reform Era. Government concerns with pesantren through pro pesantren policy.
\end{abstract}

Key words: social dynamics, pesantren

Abstract

\begin{abstract}
ABSTRAK
Pesantren merupakan sebuah lembaga pendidikan otentik Indonesia. Pesantren memiliki dinamika social di setiap periode politik Indonesia. Pra Kemerdekaan pesantren dilarang oleh pemerintah colonial Belanda. Sedangkan pada masa penjajahan Jepang pesantren diabaikan tidak dilarang dan tidak diperhatikan. Era Kemerdekaan tahun 1945 di Era Orde Lama pesantren diakomodasi oleh Pemerintahan Sukarno dengan adanya anggaran pendidikan untuk pesantren. Pesantren mendapat banyak masalah di Orde Baru, Soeharto sangat represif terhadap masyarakat Islam yang berdampak pada pesantren.Terakhir, Era Reformasi, Pemerintah sangat peduli pada perkembangan pesantren, salah satunya adalah adanya RUU Pesantren yang dirancang untuk kaumsantri melestarikan pesantren.
\end{abstract}

Kata Kunci: dinamikasosial, pesantren

\section{A. PENDAHULUAN}

Pesantren awalnya merupakan pusat penyebaran Islam oleh para wali yang merupakan kelanjutan dari sistem zawiyah di India dan Timur Tengah. Sistem pesantren bermula dari pengakuan masyarakat terhadap seorang kyai sehingga banyak masyarakat yang berdatangan pada kyai, selanjutnya orang yang belajar disebut santri.

Pendidikan Islam mempunyai sejarah yang panjang. Dalam pengertian seluasluasnya, pendidikan Islam berkembang seiring dengan kemunculan Islam itu sendiri. Kebijakan pendidikan Islam di Indonesia dapat dikategorikan dalam empat periode: Periode Pra Kemerdekaan,
Periode Orde Lama, Periode Orde Baru, Periode Reformasi. Dalam pembahasan sub bab ini hanya akan difokuskan kebijakankebijakan pendidikan Islam khususnya yang berkenaan dengan pesantren yang diterapkan oleh pemerintahan pada setiap fase.Kebijakanpesantrentersebutsangatterg antungdengandinamikasosialpolitik Indonesia.

\section{B. KAJIAN LITERATUR}

Mengkaji pesantren tidak bias terlepas dari penelitian awal yang dilakukan oleh parasarjana seperti: Karel A Stenbrink yang membukapintubagiparapenelitipesantren. Stenbrinkmengemukakanbahwapesantrent erdiridarilimaelemensepertikiai, santri, 
kitabkuning, masjid, danasrama. Selanjutnyapenelitian Martin van Bruinessen

secarakhususmengungkapkanperankitabku ningdantasawuf yang ada di pesantren.SedangkanpenelitianZamaksyari Dhoffier mengungkapkanbagaiamanpesantrenberke mbangmelaluipernikahanantarakeluargakiy ai.Tigarisetpesantreniniseringmenjadipedo manbagipenelitipesantren.

\section{METODE PENELITIAN}

Metode penelitian yang digunakan adalah penelitian kualitatif dengan pendekatan kepustakaan. Peneliti menggunakan studi pustaka dari buku-buku primer dan data sekunder mengenai pesantren. Sedangkan analisis yang digunakan adalah konten analisis. Menurut Mestika Zeid (2008:1-2) riset kepustakaan focus pada pengkajian koleksi perpustakaan.

\section{HASIL DAN ANALISIS PENELITIAN}

\section{PeriodePraKemerdekaan}

Pada periode pra kemerdekaan kebijakan pendidikan Islam dapat diklasifikasi sebagai berikut: Masa Penjajahan Belanda, Masa Penjajahan Jepang.Landasan idil pendidikan masa kolonial Belanda hanyalah dalam rangka memenuhi tenaga buruh untuk kepentingan modal, maka pada masa ini tidak begitu jelas dasarnya. Pemerintah kolonial Belanda menjalankan politik pendidikan separuh hati, karena mereka tidak menginginkan kaum pribumi memiliki kecakapan intelektual. Maka pendidikan yang diselenggarakan adalah mempersiapkan pekerja-pekerja teknis yang diperuntukkan kepentingan kolonialisme Belanda.

Nasution (2011; 10) menjelaskan beberapa ciri umum politik pendidikan pemerintah kolonial Belanda adalah:

1. Gradualisme pendidikan bagi anakanak putra pribumi.

2. Dualisme dalam pendidikan dengan menekankan perbedaan tajam antara pendidikan Belanda dan pendidikan pribumi.

3. Kontrol sentral yang kuat.

4. Keterbatasan tujuan sekolah pribumi, dan peranan sekolah untuk menghasilkan pegawai sebagai faktor penting dalam perkembangan pendidikan.

5. Prinsip konkordasi yang menyebabkan maka sekolah di Indonesia sama dengan negeri Belanda.

6. Tidak adanya perencanaan pendidikan yang sistematis untuk pendidikan anak pribumi.

Pada masa kolonial Belanda, pesantren dicurigai, ditekan, dan diintimidasi (Kraemer, 1952). Menurut Dawam Rahardjo dalam tulisannya yang berjudul "Dunia Pesantren", hal ini dikarenakan 
pesantren merupakan pusat perlawanan terhadap pemerintah kolonial. Anthony Reid mencatat bagaimana begitu takutnya pemerintah Belanda terhadap pembelajaran Al-Qur'an yang diberikan oleh para ulama di dayah kepada anak-anak Aceh (Reid, 1987; 52). Pembelajaran Al-Qur'an dianggap Belanda hanya menanamkan rasa benci dan kutukan terhadap kaum kafir. Sehingga pemerintah kolonial Belanda merasa perlu untuk membentuk sekolah dengan sistem pemerintah untuk mendisiplinkan rakyat Aceh.

Di Jawa, akibat tekanan kolonial Belanda membuat pesantren mengundurkan diri (uzlah) dan menampakkan perlawananannya dengan berada jauh di pusat pemerintahan kolonial, sehingga pesantren berada di pedesaan, pelosok kampung yang sangat sulit untuk dikunjungi orang. Walau pun pesantren mengasingkan diri dari keramaian, namun pada dasarnya pesantren juga mempersiapkan untuk memberontak pemerintah kolonial Belanda dengan memantapkan pelajaran jihad dan pelatihan fisik.

DalambukuSejarahPendidikan Islam yang diterbitkanDirjenLembagaPendidikan Islam dijelaskanbahwa sikap perlawanan pesantren terhadap pemerintah kolonial Belanda, membuat dikeluarkannya peraturan yang membatasi ruang gerak pendidikan agama, antara lain izin dari pemerintah. Langgar, surau, madrasah, dan pesantren diawasi oleh pemerintah Belanda karena dianggap sebagai tempat kaderisasi para pemberontak.

Pada tahun 1882 M pemerintah kolonial Belanda membentuk Priesterraden, sebuah lembaga yang bertugas mengawasi kehidupan beragama dan pendidikan Islam (Mubagid, 1997; 149).

SelanjutnyaMubagidmenerangkanbahwa tahun 1905 Lembaga Priesterraden memberikan rekomendasi kepada pemerintah kolonial bahwa orang yang memberikan pengajian agama harus memiliki izin pemerintah kolonial terlebih dahulu. Pada tahun 1925 M pemerintah kolonial mengeluarkan peraturan lebih ketat bahwa tidak semua kyai boleh memberikan pengajian agama. Puncaknya pada tahun $1932 \mathrm{M}$, pemerintah kolonial mengeluarkan peraturan bahwa pemerintah kolonial Belanda dapat menutup sekolah, madrasah, pesantren jika memberikan pelajaran yang tidak disukai pemerintah. Peraturan ini dikenal dengan nama Ordonasi Sekolah Liar (Wilde School Ordonantie).

Karena Politik Etis Belanda, maka poin penting kebijakan pemerintah kolonial Belanda adalah: Pertama, Pendidikan dan pengetahuan Barat diterapkan sebanyak mungkin bagi golongan penduduk Bumiputera. Untuk itu bahasa Belanda diharapkan dapat menjadi bahasa pengantar di sekolah-sekolah; Kedua, pemberian pendidikan rendah bagi golongan Bumiputera disesuaikan dengan kebuTuhan mereka. 
Azra (1997) menjelaskan modernisasi pendidikan yang diinginkan Belanda terhadap penduduk pribumi adalah dengan cara mendirikan volkschoolen, Sekolah Rakyat, atau Sekolah Desa (nagari) dengan masa belajar tiga tahun (Azra, 1997; xv)Namun menurut Azyumardi Azra sekolah umum yang didirikan Belanda ini mendapat resistensi dari masyarakat pribumi, karena mereka beranggapan bahwa sekolah-sekolah yang didirikan oleh pemerintah kolonial tersebut hanyalah untuk "membelandakan" anak mereka.

Sementara di Minangkabau, surau yang merupakan lembaga pendidikan Islam tradisional ditransformasikan secara formal menjadi sekolah nagari. Namun pada kenyataannya sekolah nagari yang pada awalnya adalah surau tersebut tidaklah sepenuhnya mengikuti kurikulum yang telah ditetapkan oleh pemerintah Belanda. Sehingga pemerintah Belanda menstandarkan kurikulum, dan metode pengajarannya. Di Bukit Tinggi pada tahun 1850 untuk pertama kali pemerintah Belanda mendirikan HIS (HollandscInlandsche School), kemudian dikenal dengan Sekolah Raja (Azra, 1997). Dari namanya saja dapat dilihat bahwa sekolah yang didirikan oleh pemerintah Belanda ini adalah sekolah khusus untuk anak-anak bangsawan.

Sistim pendidikan pemerintah kolonial Belanda yang diskriminatif membuat melebarnya jurang antara rakyat yang berorientasi Islam dan elit tradisional, priyayi yang kebanyakan terdiri dari orangorang Indonesia berpendidikan Barat. Hasbullah mengatakan dengan adanya Politik Islam dan Politik Pendidikan pemerintah kolonial Belanda yang menomorsatukan anak-anak pejabat dan pembesar mengakses pendidikan, disisi lain membatasi putra pribumi dengan mengarahkannya ke pondok-pondok pesantren justru menjadi kuatnya dasar agama Islam masyarakat (Hasbullah, 1995; 55).Menurut Nurcholish Madjid bahwa Politik Etis Belanda pada dasarnya hanya merupakan tujuan ekonomi, politik, dan sosial, sehingga berdampak banyak pribumi yang masuk sekolah umum.

Jepang yang memiliki misi untuk Asia Timur Raya untuk Asia di Indonesia, yang tujuan utamanya adalah memenangkan perang, maka berupaya merebut simpati masyarakat Indonesia dengan melakukan langkah-langkah di antaranya:

Kantor Urusan Agama (Kantoor voor Islamistische Saken) pada masa Belanda dirubah menjadi Kantor Sumubi yang dipimpin oleh ulama Islam Indonesia, yaitu K.H. Hasyim Asy'ari.

Pondok-pondok pesantren besar sering mendapat kunjungan dan bantuan dari pemerintah Jepang.Sekolah negeri diberi pelajaran budi pekerti yang isiya identik dengan ajaran agama(Zuhairini, 2010; 153).

Pemerintah Jepang mengizinkan pembentukan barisan Hisbullah yang dipimpin K.H. Zainul Arifin, dimana aktivitasnya adalah latihan dasar 
kemiliteran.Pemerintah

Jepang

mengizinkan berdirinya Sekolah Tinggi Islam di Jakarta yang dipimpin oleh K.H. Wahid Hasyim, Kahar Muzakir, dan Muhammad Hatta.Para ulama bekerjasama dan pemimpin nasionalis diizinkan mendirikan barisan Pembela Tanah Air.Umat Islam diizinkan meneruskan organisasi persatuan yang disebut Majelis A'la Indonesia (Zuhairini, 2010; 153).

Masa pendudukan Jepang tahun 1940 an, Jepang berencana mendirikan "Kemakmuran Bersama Asia Raya". Untuk mewujudkan itu, maka ideologi pendidikan yang diterapkan adalah Hakko Ichiu. Tujuan pendidikan Jepang yang utamanya adalah memenangkan perang. Pelajar yang dipersiapkan untuk perang tersebut membuat aktivitas di sekolah lebih banyak kepada latihan fisik dan latihan kemiliteran dan indoktrinasi "Asia untuk Bangsa Asia." Pada masa pendudukan Jepang ini sistem pendidikan yang telah dibangun Belanda semuanya dirubah, termasuk satuan-satuan pendidikannya, hanya beberapa saja yang masih dipertahankan, misalnya Sekolah Tinggi Kedokteran (Ika Dai Gakko) di Jakarta, Sekolah Teknik Tinggi (Kogyo Dai Gakko) di Bandung. Akses pendidikan juga dibuka luas, tidak ada lagi segeregasi sosial sebagaimana yang diterapkan pemerintah kolonial Belanda. Sekolah-sekolah diseragamkan menjadi negeri, namun sekolah Muhammadiyah, dan Taman Siswa tetap berkembang dengan pengawasan Jepang.
Pada masa pendudukan Jepang (1942 1945) pemerintah Jepang kurang perhatian terhadap pendidikan di pondok pesantren dan madrasah. Ma'arif tetap dapat bisa bergerak walau terbatas dalam mengelola pondok pesantren dan madrasah. Menurut Zuhairini ketika sekolah non pesantren dilatih baris berbaris, romusha, latihan fisik, pesantren terlepas dari kegiatan ini semua, maka proses belajar berjalan relatif lancer(Zuhairini, 2010; 153).

Sebagai lembaga pendidikan yang merupakan bagian dari NU, Ma'arif masa pendudukan Jepang telah memiliki Madrasah Menengah (Madrasah Mu'allimin Mustha), Madrasah Guru Atas (Madrasah Mu'allimin Ulya), Madrasaut Tijarah (Sekolah Ekonomi Dagang), Sekolah Pertukangan (Madrasatus Shina'ah), Sekolah Pertanian (Madratus Zira'ah). Uniknya pendidikan kejuruan yang dikelola oleh Ma'arif ini sebenarnya tidak boleh didirikan, namun karena Jepang tidak begitu peduli dengan lembaga pendidikan Islam, maka madrasah Ma'arif tetap berjalan.

\section{PesantrenPeriodeOrde Lama}

Pada tanggal 29 Desember 1945 Badan Pekerja KNIP mengusulkan kepada Kementerian Pendidikan,Pengajaran, dan Kebudayaan agar segera malakukan reformasi pendidikan dan pengajaran. Pokok-pokok yang direkomendasikan Badan Pekerja KNIP ada sembilan poin, terdapat satu poin nomor 4. "Madrasah dan pesantren-pesantren yang pada hakikatnya adalah satu alat dan sumber pendidikan 
dan pencerdasan rakyat jelata, yang sudah berurat berakar dalam masyarakat Indonesia umumnya, hendaklah pula mendapat perhatian dan bantuan yang nyata dengan berupa tuntunan dan bantuan materiil pemerintah."

Atas saran BPKNIP di atas, Pemerintah melalui Panitia Penyelidik Pengajaran yang diketuai oleh Ki Hajar Dewantara menegaskan,"bahwa pengajaran yang bersifat pondok pesantren dan madrasah perlu untuk dipertinggi dan dimodernisasikan serta diberikan bantuan biaya dan lain-lain."(Depag, 2003; 13). Perhatian pemerintah terhadap pondok pesantren dan madrasah direalisasikan dengan menjadikan pendidikan agama dan pendidikan keagamaan sebagai bagian penting dalam tugas Departemen Agama yang dibentuk pada tanggal 3 Januari 1946. Sejak penyelenggaraan pendidikan diatur negara melalui UU Nomor.4 tahun 1950 tentang dasar-dasar pendidikan dan pengajaran maka pesantren mulai melakukan adaptasi.

Walau pun Indonesia telah merdeka pada tanggal 17 Agustus 1945 namun pihak Belanda dan Sekutu masih berupaya masuk kembali ke Indonesia. Melihat kondisi ini membuat ulama-ulama di Jawa pada tanggal 20 Oktober 1945 mengeluarkan Fatwa Jihad Fisabilillah terhadap Belanda dan sekutu. Konsekwensi dari Resolusi Jihad tersebut membuat para ulama dan santrinya dapat mempraktikkan ajaran jihad fi sabilillah yang sudah menjadi tradisi sebagai bahan kajian di pondok pesantren dan madrasah.

\section{PesantrenPeriodeOrdeBaru}

Andre Feillard (2001, 185-186) menjelaskan salah satu prioritas Orde Baru adalah pembangunan sistem pendidikan modern. Dengan sejumlah besar anak-anak sekolah dan terbatasnya sumber-sumber nasional, kebijakan pemerintah berusaha mengkoordinasikan aktivitas-aktivitas pemerintah berusaha mengkoordinasikan aktivitas-aktivitas pemerintahan dengan sekolah-sekolah swasta, termasuk sekolahsekolah Islam. Mahmud Suyuthi menjelaskan bahwa posisi pesantren pada masa Orde Baru tidak bisa terlepas dari kerangka besar yang membingkainya, yaitu hubungan Islam dan negara di Indonesia yang mengalami Fase Ketegangan, Fase Pencarian, dan Fase Hubungan Islam dan negara. Pada masa Orde Baru hegemoni negara sangat mempengaruhi perkembangan pondok pesantren di Indonesia. Soeharto dengan tafsir tunggal Pancasila nya menginginkan pondok pesantren tetap harus berlandaskan pada Pancasila.

Pada masa Orde Baru Pondok Pesantren Persatuan Islam (Persis) melawan mainstream seperti yang dilakukan Nahdlataul Ulama dan Muhammadiyah untuk konsiliasi dengan pemerintah, Persis dengan pesantrennya memilih sikap kesadaran yang bertentangan (Soeharto, 2012). Andre Feillard dalam penelitiannya 
di Jawa Timur menemukan terdapat dua pesantren yang melawan mainstream untuk menerapkan Penatara P4 (Pedoman Penghayatan dan Pengamalan Pancasila), yaitu Pondok Pesantren Nurud Dlolam pimpinan Kyai Siraji dan Pesantren Salafiyahal-Fatah, Malang.Kasus di tiga pondok pesantren ini mencerminkan bagaimana pemerintah Orde Baru memandang pondok pesantren sebagai ancaman bagi keberlangsungan ideologi Pancasila.

Secara alamiah, dengan dana pemerintah yang lebih besar, berpotensi adanya intervensi pemerintah dalam masalah-masalah pendidikan. Andre Feillard mencatat bahwa meningkatnya peran pemerintah Orde Baru membuat banyak madrasah dan pesantren yang tidak berafiliasi dengan NU. Analisis Feillard bahwa menurunnya peran NU dalam pendidikan ini dikarenakan adanya tekanan pejabat daerah yang terjadi tahun 1970-an. Sehingga banyak madrasah dan pesantren yang tidak mengidentifikasikan dirinya dengan NU, melainkan berkamuflase atau merubah namanya, misalnya Sekolah Wahid Hasyim, atau Universitas NU yang menjadi Universitas Sunan Giri. Agaknya tesis Feillard tentang bantuan dana pemerintah akan bisa intervensi lembaga pendidikan dapat dilihat dengan mengaburnya identitas madrasah dan pesantren NU, karena banyak yang masih sangat minim dalam soal finansial, sehingga sangat tergantung pada pemerintah dalam hal ini Departemen Agama.

Pada masa Orde Baru dari berbagai varian bentuk pesantren dengan Peraturan Menteri Agama Nomor 3 Tahun 1979 tentang Bantuan kepada Pondok Pesantren, maka pesantren dikategorikan menjadi empat:

1. Pondok pesantren Tipe A yaitu pondok yang seluruhnya dilaksanakan secara tradisional.

2. Pondok pesantren Tipe B yaitu pondok yang menyelenggarakan pengajaran secara klasikal (madrasi).

3. Pondok pesantren Tipe C pondok pesantren yang hanya merupakan asrama sedangkan santrinya belajar di luar.

4. Pondok pesantren Tipe D yaitu pondok pesantren yang menyelenggarakan sistem pondok pesantren dan sekaligus sistem sekolah atau madrasah (DirjenKelembagaan Islam, 2003)

Pesantren sangat sulit dimasukkan apa adanya ke dalam Undang-undang Sisdiknas Nomor 20 tahun 2003. Karena pesantren lebih suka mengkategorikan diri mereka sebagai sebuah sistem, sebagaimana dikatakan oleh Abdurrahman Wahid bahwa pesantren merupakan subkultur tersendiri dalam masyarakat Islam (DepagRI, 2005; 76). Atas dasar ini Direktori Kelembagaan Islam Departemen Agama bahwa pada dasarnya pesantren tidak bersenTuhan langsung dengan UU 
Sisdiknas No 2003 tetapi hanya lembagalembaga pendidikan Islam di dalamnya, maka perlu pemberdayaan lembaga pendidikan yang ada pada pesantren.Konsekwensi paradigma ini maka program pendidikan di pesantren dapat dibagi menjadi dua: Pertama, satuan atau program yang sudah diatur pemerintah, misalnya MI, SMA, SMK, dan perguruan tinggi umum; Kedua, satuan atau program pendidikan yang selama ini tidak mengikuti aturan kurikulum negara, misalnya: madrasah diniyah, kuliyatul muallimin, diniyah salafiyah, majlis taklim.

\section{Pesantren Era Reformasi}

Variasi bentuk pesantren di era reformasi menurut data Direktorat Jenderal Kelembagaan Islam Departemen Agama terdapat tujuh varian, dan sangat berbeda sebagaimana yang dikategorisasi dan simplikasi pada Masa Orde Baru yang hanya ada empat kategori.

1. Pondok pesantren yang menyelenggarakan pengajian kitab kuning.

2. Pondok pesantren yang mempelajari kitab kuning namun juga memberikan pelatihan keterampilan pada para santri dalam bidang kejuruan tertentu.

3. Pondok pesantren yang mengkaji kitab kuning namun lebih mengembangkan tarekat, dimana santrinya ada yang diasrama ada yang tidak.
4. Pondok pesantren yang menyelenggarakan keterampilan khusus agama Islam, seperti menghafal Al-Qur'an. Santrinya ada yang di asrama ada juga yang di luar pesantren.

5. Pondok pesantren yang menyelenggarakan pengajaran bagi para penyandang masalah sosial, yaitu Madrasah Luar Biasa di pondok pesantren.

6. Pondok pesantren yang menyelenggarakan pengajian kitabkitab klasik namun juga menyelenggarakan kegiatan pendidikan formal ke dalam lingkungan pondok pesantren.

7. Pondok pesantren yang merupakan kombinasi dari beberapa poin di atas (DirjenKelembagaan Islam, 2005; 16).

Pada Era Reformasi sebagaimana tercatat dalam situs resmi Direktori Pendidikan Kementerian Agama pada tahun 2007-2008 dari 33 provinsi tercatat 21.521 pondok pesantren dan 37.102 madrasah diniyah. Jika dikateorikan terdapat tiga tipe pondok pesantren: Salafiyah, 8.001 (37,2\%); Ashriyah, 3,881 (18,0\%); Kombinasi, 9.639 (44,8\%). Sedangkan jumlah santri secara keseluruhan 3.818.469 santri, terdiri santri laki laki $2.063 .954 \quad(54,1 \%)$, dan santri perempuan 1.754 .515 (45,9\%). Sementara jumlah tenaga pengajar pondok pesantren secara keseluruhan berjumlah 385.994 
orang, dari jumlah tersebut yang berstatus kyai sejumlah $35.113(9,1 \%)$, badal kyai $224.332(58,1 \%)$, ustadz berjumlah 71.139 $(18,4 \%)$ merupakan dosen. Sedangkan pondok pesantren penyelenggara Program Paket A, B, dan C tercatat 338 pondok pesantren penyelenggara Paket A, 575 penyelenggara Paket B, dan 902 penyelenggara Paket $C$. Keseluruhan siswa yang mengikuti program Paket A,B,dan C adalah 94.994 orang siswa. Jika dirinci lagi 13.450 orang Paket A, 27.400 orang Paket B, dan 54.054 orang ikut Paket C. Jumlah total tutor 8.800 tutor, 1.616 tutor Paket A, 3.952 tutor Paket B, dan 3.233 tutor Paket C (DirektoriPendis, 2014).

Di era KepemimpinanPresidenJokoWidodo, pesantrenmendapatperhatiankhususdenga nadanya

Pesantren.Namunpadasaatini RUU Pesantrenmasihdiproses di DPR RI.Melalui RUU

Pesantrendiharapkanpesantrenakanmenda patkanporsianggaran di APBN dan APBD.

\section{PENUTUP}

Dinamikasosialpesantren di Indonesia terbagiperiode: PraKemerdekaan; Orde Lama, OrdeBaru; dan Era Reformasi. Pada Era

PraKemerdekaanPemerintahkolonialBeland amenghambat, mempersulitbahkanmelarangpesantrenkare nadianggapsebagaisumberperlawananterha dapPemerintahKolonial.Sedangkan di Era
KolonialJepang,

pesantrentidakmendapatkanperhatiankare naJepangfokusmenghapuskebijakanPemeri ntahKolonialBelanda.

PadamasaOrde Lama, pesantrendianggapsebagailembagapendidik an

yang

berakardanmerupakanotentiklembagapend idikankhas Indonesia, sehinggaperludimasukkandalamanggaran Negara.SedangkanmasaOrdeBaru, pesantrendianggapPemerintahSoehartoseb agaiancamanterhadap ideology Pancasila, sehinggabanyakkebijakanpendidikantidakb erpihakbagikalangansantri.Di masaReformasi, pesantrendianggapsebagai modal

sosialsehinggapesantrenmendapatkanperha tiankhususdaripemerintah, terbuktidenganadanya RUU Pesantren. 
Bruinessen, Van Martin, Kitab Kuning Pesantren dan Tarekat, Bandung: Mizan, 1999.

Dhofier, Zamakhsyari, TradisiPesantren: StudiPandanganHidupKyaidanVisiny amengenaiMasaDepan Indonesia, Jakarta: LP3ES, 1994.

Dirjen Kelembagaan Islam, Pondok Pesantren dan Madrasah Diniyah: Pertumbuhan dan Perkembangannya, Jakarta: Depag RI, 2003.

Dirjen Kelembagaan Islam, Paradigma Islam dan Pendidikan Nasional: Paradigma Baru, Jakarta: Depag RI, 2005.

Hasbullah, Sejarah Pendidikan Islam: Lintasan Sejarah Pertumbuhan dan Perkembangannya, Jakarta: PT RajaGrafindo Persada, 1995.

Kraemer, Agama Islam, Jakarta: Badan Penerbit Kristen, 1952.

Mubagid,HR, Diktat Kuliah Sejarah Pendidikan Islam dalam Zuhairini (dkk), Sejarah Pendidikan Islam, Jakarta: Departemen Agama dan Bumi Aksara, 1997.

Nasution, Sejarah Pendidikan Indonesia, Jakarta: Bumi Aksara, 2011.

Reid, Anthony, The Blood of the People: Revolution and the End of Traditional Rule in Northern Sumatra, Jakarta: Pustaka Sinar Harapan, 1987.

Feillard, Andre, Islam Tradisionalis dan Negara di Indonesia: Jalan Menuju Legitimasi dan Kebangkitan, dalam Robert W.Hefner dan Patricia Horvatich (Ed), Islam di Era Negara Bangsa: Politik dan Kebangkitan Agama Muslim Asia Tenggara, Yogyakarta: Tiara Wacana,2001.

Soeharto, Toto, Kesadaran yang Bertentangan sebagai Bentuk Resolusi Konflik dalam Pendidikan: Pengalaman Pesantren
Persatuan Islam di Masa Orde Baru. Jurnal Analitis, Volume XVII, Nomor 2, Desember 2012.

Stanton, Charles Michael, Pendidikan Tinggi dalam Islam, Jakarta: Logos, 1994.

Steenbrink, A. Karel, Pesantren, Madrasah, Sekolah: Pendidikan Islam dalamKurunModeren, Jakarta: LP3ES, 1994.Zuhairini, Sejarah Pendidikan Islam, Jakarta: BumiAksara, 2010.

Zed, Mestika, 2008.Metode Penelitian kepustakaan, Jakarta : Yayasan Obor Indonesia 